This document was prepared in conjunction with work accomplished under Contract No. DE-AC09-96SR18500 with the U. S. Department of Energy.

\title{
DISCLAIMER
}

This report was prepared as an account of work sponsored by an agency of the United States Government. Neither the United States Government nor any agency thereof, nor any of their employees, makes any warranty, express or implied, or assumes any legal liability or responsibility for the accuracy, completeness, or usefulness of any information, apparatus, product or process disclosed, or represents that its use would not infringe privately owned rights. Reference herein to any specific commercial product, process or service by trade name, trademark, manufacturer, or otherwise does not necessarily constitute or imply its endorsement, recommendation, or favoring by the United States Government or any agency thereof. The views and opinions of authors expressed herein do not necessarily state or reflect those of the United States Government or any agency thereof.

This report has been reproduced directly from the best available copy.

Available for sale to the public, in paper, from: U.S. Department of Commerce, National Technical Information Service, 5285 Port Royal Road, Springfield, VA 22161, phone: (800) 553-6847, fax: (703) 605-6900

email: orders@ ntis.fedworld.gov

online ordering: http://www.ntis.gov/support/index.html

Available electronically at http://www.osti.gov/bridge

Available for a processing fee to U.S. Department of Energy and its contractors, in paper, from: U.S. Department of Energy, Office of Scientific and Technical Information, P.O. Box 62, Oak Ridge, TN 37831-0062,

phone: (865)576-8401,

fax: (865)576-5728

email: $\underline{\text { reports@ adonis.osti.gov }}$ 
WSRC-MS-2002-00476

\section{Strain Gage Test Results of Band-Type Locking Rings for a Typical Drum Type Radioactive Material Package.}

\author{
Charles A. McKeel \\ Westinghouse Savannah River Co. \\ Aiken, SC 29808 \\ (803) 952-9127, charles.mckeel@srs.gov
}

\author{
Allen C. Smith \\ Westinghouse Savannah River Co. \\ Aiken, SC 29808 \\ (803) 725-2943, allen.smith@srs.gov
}

\begin{abstract}
Band type closure rings are commonly used for securing the drum lid on radioactive material packages of lower weight classifications. Lid installation is achieved by placing the band around the perimeter of the lidded drum and tightening the single bolt in stages until a designated torque value is obtained. The band is subjected to heavy rapping with a soft hammer during installation to equilibrate the band strains around the drum perimeter. The study described here investigated the strain distributions in the band throughout the installation process. The results show that a uniform strain distribution is achieved during installation and that the hammering of the band aids in achieving the uniform distribution. The results of the strain levels after the drop test indicate that the locking rings maintain some pretension, even after severe targeted drops that crush a portion of the drum top.
\end{abstract}

\section{INTRODUCTION}

Band type closures employing a single bolt closure mechanism are advantageous for radioactive material packages because of the ease and speed of obtaining a sealed drum. A typical closure ring consists of a metal band with a C-shaped cross-section encompassing the perimeter of the drum and incorporates a single bolt closure mechanism. These closure rings are used successfully in industry for the lower weight classification drums and have passed 10 CFR 71 Hypothetical Accident Condition (HAC) testing involving severe drops onto hard surfaces.

\section{TEST PROGRAM}

The purpose of this investigation was to quantify the distributions of strains around the drum perimeter for a band type locking ring on a typical drum type radioactive material package. Strain gages were mounted around the perimeter of the closure ring on drums being prepared for subsequent HAC testing. The intent was to monitor the band strain levels during the lid installation process and after the drop tests.

Three identical drums used in HAC drop tests were instrumented with strain gages around the band perimeter. The gages were mounted to the rings prior to placing the rings around the drum. Lid installation tests were performed twice on each of the three drums. After final lid installation, two of the drums were subjected to three successive drop tests. The drop tests consisted of a 4 foot pre-conditioning drop, a 30 foot drop, and a one meter pin-drop. All gages and instrumentation were calibrated for static condition strains. Strain data recorded during and after the drop test is considered information only, due to the dynamic and destructive nature of these type tests.

\section{CONFIGURATION}

Four general purpose constantan strain gages were equally spaced onto each closure ring and oriented so as to measure circumferential direction strains in the band. The gage locations shown in Figure 1 were used on all three test packages and were chosen to not directly interfere with target points in the drop tests. The strain gages used were Micro-Measurements Model Number 
CEA-09-125UN-120 with lead compensation wire employed. Attachment of the gages was by cyanoacrylate bonding and the gages and terminal pads were covered with protective RTV. Data acquisition was accomplished via Vishay Model 2110 strain gage conditioner and amplifier and an Astro-Med Dash 8 Portable 8Channel Field Recorder.

\section{Lid Installation Procedure}

The lid installation procedure used for the tested drums is typical of all such drums. The lid is placed over the drum with the lid curl fitting loosely over the drum top curl. The closure ring is then placed around the lid curl by hand, aided by use of a soft rubber hammer as required, encompassing the drum and lid curls. The closure bolt is then torqued to $50(+5 /-0)$ foot-pounds while the outer edge of the ring is rapped with a soft-faced rubber hammer (Westinghouse, 2000). The end gap on the closure ring at $50 \mathrm{ft}$-lb torque must be greater than $1 / 4 \mathrm{in}$. to prevent pinching together of the ends. If the locking ring ends come to within $1 / 4$ in. of each other, a different locking ring and drum lid combination is used.

\section{Estimation of Pre-Load Strain}

Using standard equations for screw threads, the pre-load from the application of $50 \mathrm{ft}-\mathrm{lb}$ of torque was estimated. The force range was determined to be from $4800 \mathrm{lbs}$ to $6000 \mathrm{lbs}$, depending on bolt friction. The magnitude of strain expected during the pre-load is estimated to provide a comparison point for the test results and to select test instrumentation settings. This force results in band strain level above that corresponding to the nominal yield strength. Using the locking rings cross-sectional area of $\mathrm{A}=0.1729 \mathrm{in}^{2}$ and the Young's Modulus for the $304 \mathrm{~L}$ material $(\mathrm{E}=28.3 \mathrm{E} 6 \mathrm{psi})$, the minimum expected strain is computed as:

$$
\begin{aligned}
& \sigma=\frac{F}{A} ; E=\frac{\sigma}{\varepsilon} \Rightarrow \\
& \varepsilon=\frac{F}{E A}=\frac{4800 \mathrm{lbs}}{28.3 E 6 \mathrm{psi} \times 0.1729 \mathrm{in}^{2}}=0.000981 \mathrm{in} / \mathrm{in}
\end{aligned}
$$

The strain corresponding to the nominal yield stress of 25,000 psi is:

$\varepsilon=\frac{\sigma_{\text {yield }}}{E}=\frac{25,000 \mathrm{psi}}{28.3 E 6 \mathrm{psi}}=0.000883 \mathrm{in} / \mathrm{in}$

\section{Voltage to Strain Conversion}

The amplifier gain on the recorder is set by shunting one leg of the strain gage whetstone bridge with a calibration resistance. The output voltage was set to the desired value by adjusting the amplifier gain. Because of the long length of wires used in this test, the calibration strain is modified to account for the long wires used during the test.

$$
\varepsilon_{c a l}=\frac{R_{a}^{\prime}}{K^{\prime}\left(R_{c a l}+R_{a}^{\prime}\right)}
$$

where :

$$
\begin{aligned}
& R_{a}^{\prime}=\text { shunted resistance }=350 \Omega \\
& R_{c a l}=\text { Shunt Cal resistance }=174,650 \Omega \\
& K^{\prime}=\text { eff. gage factor } \\
& =\text { gage factor } * \text { wire resistance factor } \\
& =2.070 \times \frac{120 \Omega}{120 \Omega+0.043 \frac{\Omega}{f t} \times 35 f t}=2.0444 \\
& \varepsilon_{c a l}=\frac{350 \Omega}{2.0444(174,650 \Omega+350 \Omega)}=0.0009783 \mathrm{in} / \mathrm{in}
\end{aligned}
$$

The calibration strain is similar to the expected strain range during the lid installation. The gain control for each strain gage circuit on the Vishay amplifier/conditioner was set to equate the calibration strain to the AstroMed Dash 8 full scale reading of four volts. The scale factor resulting from the calibration strain to voltage relation is:

$$
\text { Scale Factor }=\frac{0.0009783 \mathrm{in} / \mathrm{in}}{4 \text { volts }}=0.0002446 \frac{\varepsilon}{\text { volt }}
$$

\section{Installation Test Data Results}

The voltage readings during the installation were monitored continuously using the Dash 8 strip recorder. A typical strip chart recording during a portion of the lid installation is shown in Figure 3. The final voltage output from each strain gage circuit after lid installation was recorded using a Fluke Multimeter. Table 1 summarizes the strain results for the lid installation tests. Figure 2 shows the variation of the final strain around the circumference of the closure band. The first lid installations on the three drums are shown with dashed lines, the second lid installation test are shown with the solid lines.

The highest strains were consistently recorded at the number three position, which is nearest to the closure bolt. The strains at this position for the three drums during the first tests were $132 \%$, $136 \%$ and $127 \%$ of the nominal yield strain. For the second tests, the corresponding strains were $113 \%, 125 \%$ and $118 \%$ of the nominal yield strain. The lowest strains were consistently recorded at the \#4 position, which is farthest from the closure bolt. The strains at this positions for the three drums were $75 \%$, $62 \%$, and $52 \%$ of the nominal yield strain during the first lid installations and 96\%, 61\% and $76 \%$ during the second installations. 
Rapping of the band with the soft hammer produced the consistent effect of reducing the strains at the number two and three positions and increasing the strains at the number one and four positions. The strain reduction tended to be more dramatic than the strain increases during rapping. Typically, a strain reduction of $20 \%$ to $30 \%$ at the number three position would occur with a $10 \%$ increase at the number one and four positions.

\section{Drop Tests}

Two drums were subjected to three drop tests each. The first test was a 4 foot precondition drop, the second test was the 30 foot drop test, and the third test was a one meter "pin drop" test. The pre-condition and 30 foot drops were onto a flat, rigid surface, the last test dropped the drum onto a 6 inch diameter steel post with first contact occurring on the closure bolt. The drum orientations used during the 30 foot drop test had the drum center axis inclined 17 degrees (drum 4) and 45 degrees (drum 5) from horizontal in a top-down configuration. The same data acquisition system used in the lid installation was utilized to record strain data.

The closure band deforms significantly in the areas that are directly targeted for the drop impact. Strains in these areas will be large, possibly greater than the $3 \%$ strain limit of the gages, and any gage in these areas will most likely be damaged. As the focus of the test was to determine what level of band tension was maintained in the undamaged areas of the closure, all amplifier settings and voltage scale factors were maintained from the lid installation test. For the drum 5 pin drop, and all of the drum 4 drops, the strain gage scale factor was doubled to $0.0004892 \mathrm{in} / \mathrm{in}$ per volt.

\section{Drop Test Results}

For the number four drum specimen, the precondition drop resulted in an indicated strain loss of $20 \%$ (gage positions 2 and 3 ) to $40 \%$ at position 1 , as shown in Table 2 . The strip chart recording is shown in Fig. 4. The position four gage was lost at impact as it was near the targeted ground contact point. The remaining gage readings fluctuated for $200 \mathrm{~ms}$ at impact before stabilizing with additional output spikes occurring as the drum bounced. The results for the 30 foot drop, shown in Table 3, were qualitatively similar. The target contact point was near the number three position and this strain gage was lost upon impact. The number one gage indicated a $60 \%$ reduction in strain and the number two gage indicated compression. Before the one meter pin drop test, a voltage offset was applied to the remaining two strain gage circuits, so only strain change can be recorded. The results are shown in Table 4.

The pre-condition, 30 foot, and one meter pin drop test results for the number five drum are shown in Tables 5 through 7. The drop tests on this drum produced strain results similar to the number four drum. For the pre-condition drop, the number four gage was again lost and the remaining gages all recorded a reduction in strain of no more than $50 \%$ of the pre-tension strain. The 30 foot drop resulted a slight increase in strain at the number one position, a slight decrease at the number two potions and a large increase, beyond the gage signal conditioner accuracy limits, at the \#3 position. Before the one meter pin drop test, a voltage offset was applied to the strain gage circuits, so only strain change can be recorded. Figure 5 shows a time history of strain gage output during the pin drop. The results are shown in Table 7 .

\section{Discussion}

$\underline{\text { Installation }}$

The strain levels recorded in the closure band during the lid installations were in agreement with the estimated results. The average strain recorded around the periphery of the closure band was $95 \%$ of the nominal yield strain $(\propto 25 \mathrm{Ksi}$ ), compared to a predicted value of $111 \%$. Strains were higher at positions closet to the closure bolt. The strains at position \#3 were the highest, with an average value of about $132 \%$ of the yield strain for all three drums during the first installations and about $119 \%$ during the second installation. The corresponding average strains at the \#4 position were $63 \%$ and $78 \%$.

As the closure bolt was tightened, the gages nearest to the closure bolt (\#2 and \#3 gages) showed the higher strain increases. The variations of the strain at position \#3 was likely due to the fact that the force required to apply the torque would cause the band to move (in a vertical direction) relative to the drum curl. The applied torque to the bolt causes the portion of the band near the closure bolt to shift slightly vertically, and then to be held "off center" by friction. The rapping allows the friction to be overcome and the band to return closer to its "center" position, which reduces the strain. Physical observations during the test, which showed that the \#3 position strains would rise as the torque was applied and immediately reduce when the torque was removed, supports this hypothesis. This explanation also supports the fact that the gages indicating below average strains do not increase in strain as much as the higher reading gages (\#3) decrease in strain.

The rapping of the band with the soft hammer produced the consistent effect of reducing the strain levels at the number three position and increasing the strains at the number four positions. The rapping also explains the reduction of three position final strains from the first series of lid installations to the second series with the corresponding strain increase at the four position. Qualitative observations made during the second lid installations indicate more forceful rapping with the soft hammer, resulting in a higher degree of load equalization.

The only anomaly in the test was the relative strain levels at position \#2 and \#1. Based on the location of the four strain gages relative to the closure bolt, it would be expected that the strain at the \#1 and \#4 positions would be dependent upon the strain at the \#3 and \#2 positions. Specifically, it would be expected that the strain at position \#1 would not exceed the strain at both the \#2 position and \#4 position and that the \#4 strain could not exceed both the \#3 and the \#1 strain. The readings at the \#4 position consistently passed the above test, whereas the strain at the \#1 position consistently failed the test. This is clearly shown in 
Figure 2, which plots the variance in strain around the perimeter, starting at the bolt location and moving clock-wise $(\mathrm{CW})$ around the drum perimeter. This distribution was present in four of the six installation tests, the voltages were read using the same instrument, and all the various gage bridge circuits were pretested during an initial verification.

One possible explanation for the high readings at the \#1 position is that local bending strains are occurring at this position. As the strain gages are mounted on the external surface of the band, the strain recorded includes the membrane and bending strains. Because the band's C-shaped cross-section has some bending strength, it is possible that the position of the \# 1 gage was subject to an additional bending stress as the band ends were tightened together.

\section{Drops}

A qualitative review of the output from the strain gages shows a short duration change in the closure band strain at impact, in either the tension or compression direction. The band strains then return to a new fixed value. The strain behavior at the time of impact does indicate that the band could lose pre-tension for a very short time at impact. However, for every drop test performed, at least one gage still indicated a significant amount of pre-tension.

These results from the strain gages are consistent with the observations from the high speed video of the drop tests, and the subsequent examination of the assembly (Smith, 2000). In the video, some relative movement was observed between the drum and the closure band during the impact transient. This is consistent with the changing values in strain observed in the strain gages. Following the impact, the closure ring remained tightly mechanically engaged with the drum curl and the lid. This is consistent with the indications of tension in the closure band in the post test condition shown by the strain gages.

\section{Figures and Tables}
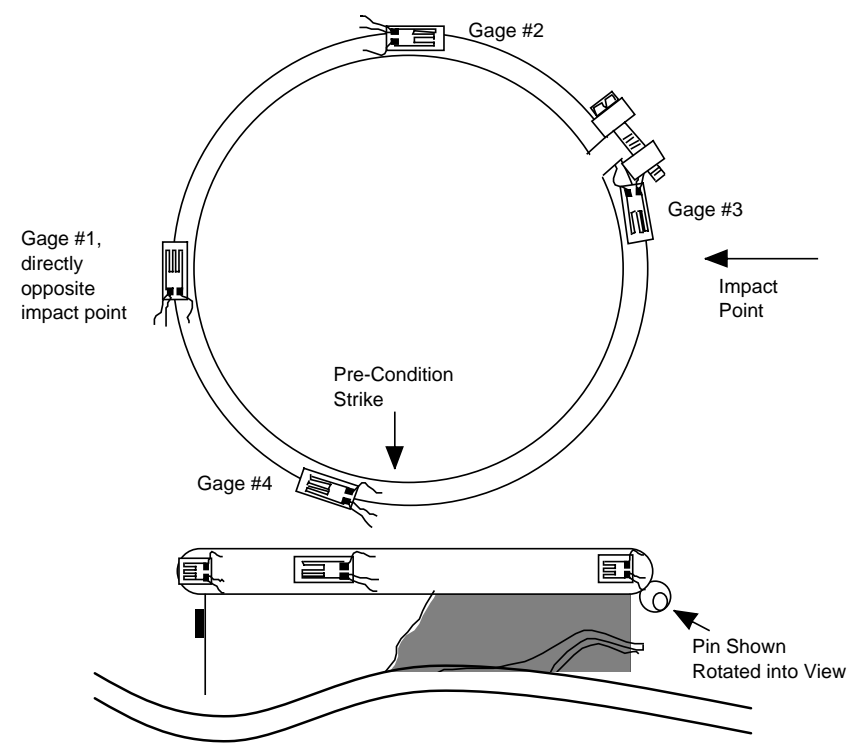

Figure 1 Test Configuration

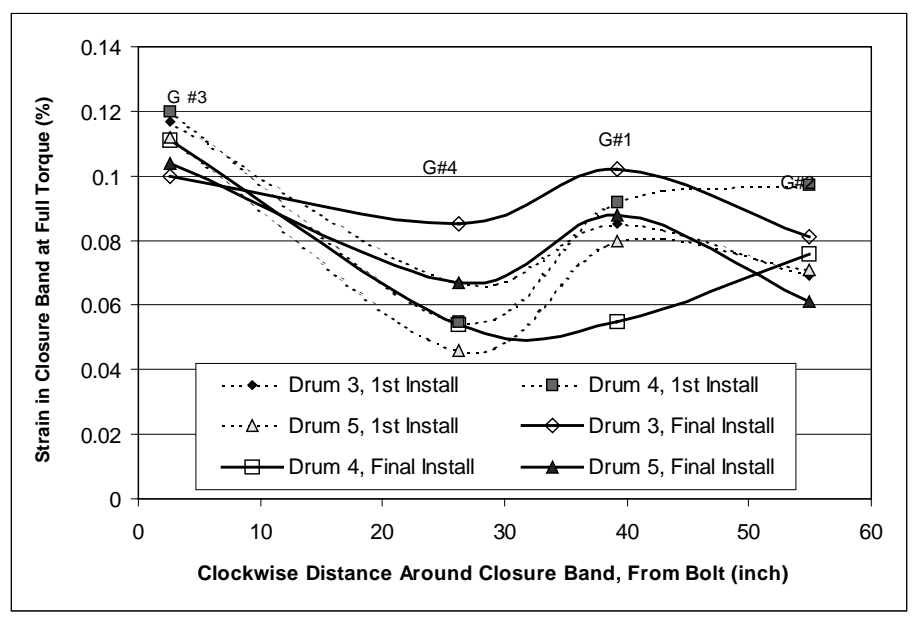

Figure 2 Variation of Strain Around Banded Closure

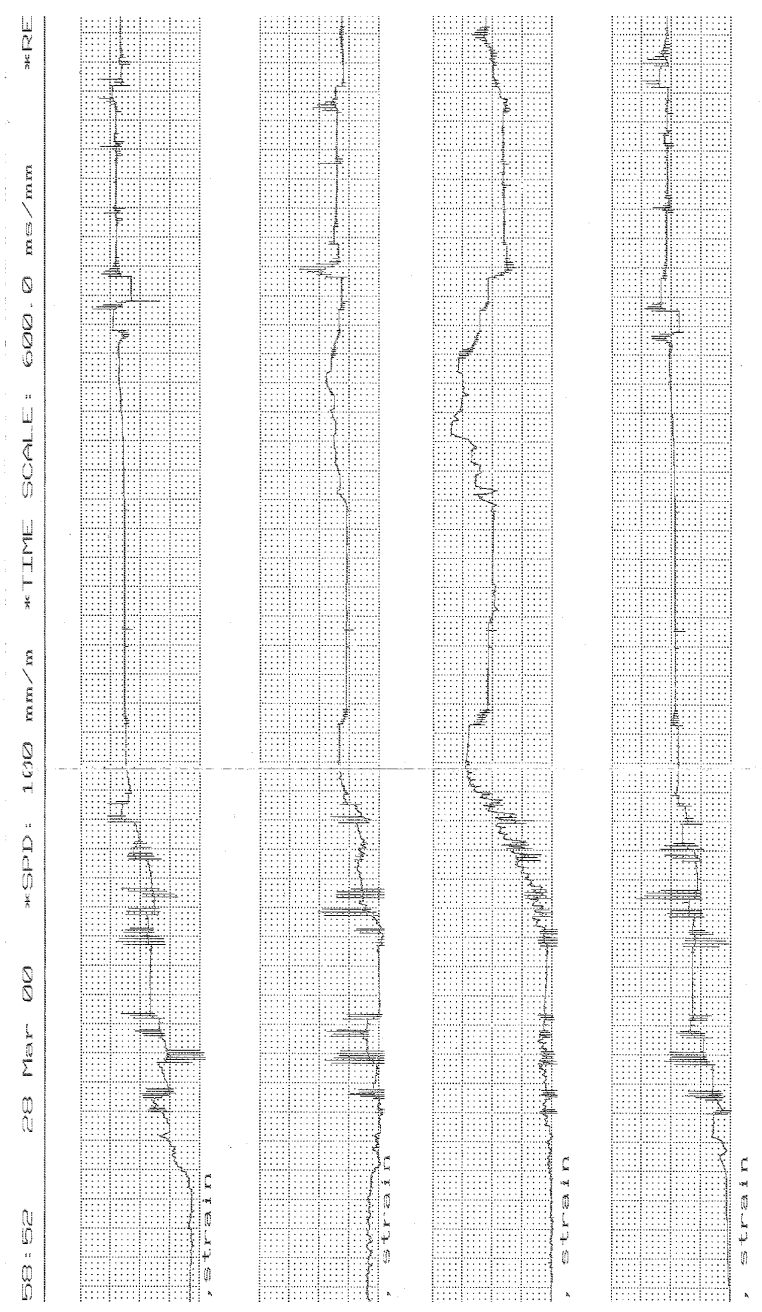

Figure 3 Strain Gage Readings During Closure Band Installation 

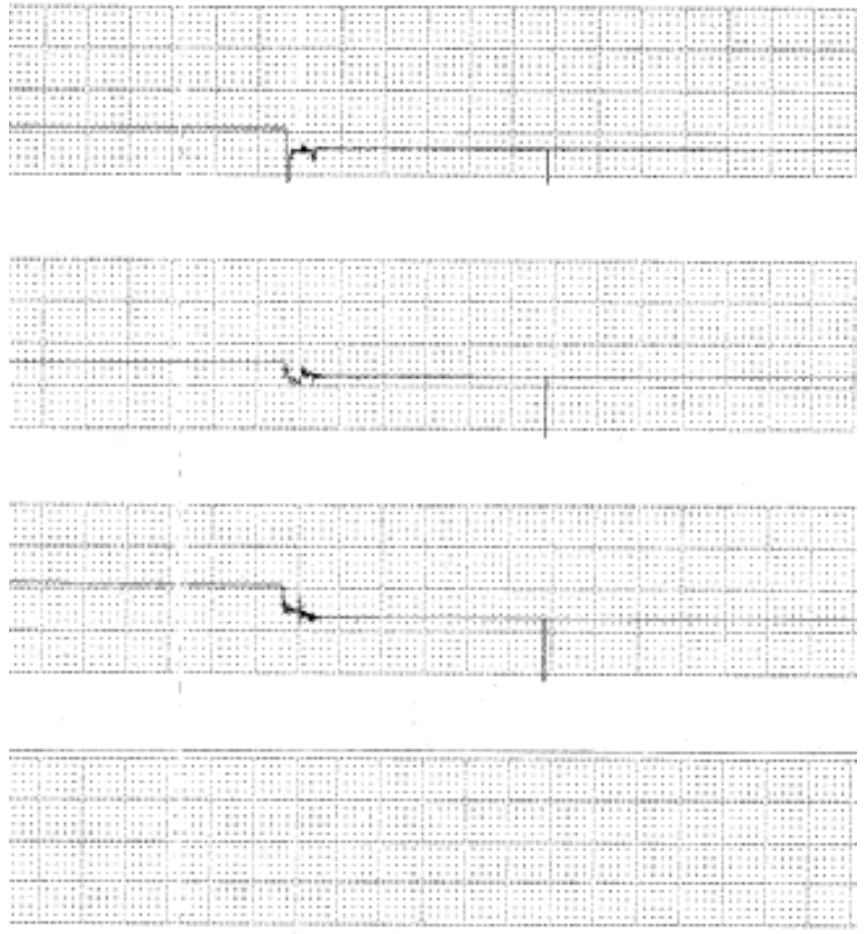

Figure 4 Strip Chart Recording at Instance of Ground Impact. (Chart Speed $=20 \mathrm{~ms} / \mathrm{mm}$, above picture not to scale)

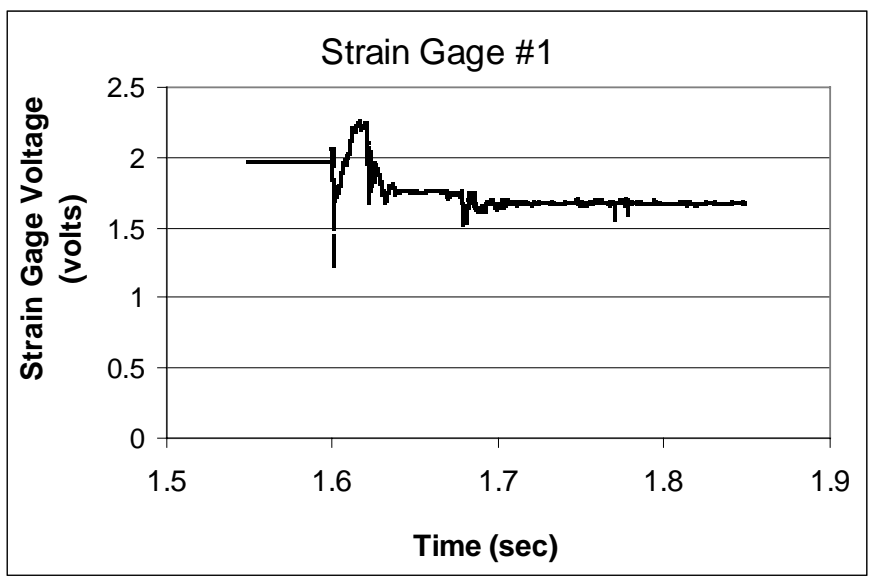

Figure 5 Plot from Electronic Data for Strain Gage \#1, Drum \#5 Pin Drop Test

Table 1 Summary of Strain Gage Data Obtained During Drum Lid Installation.

\begin{tabular}{|c|c|c|c|c|c|c|c|c|}
\hline $\begin{array}{c}\text { Drum } \\
\#\end{array}$ & $\begin{array}{c}\text { Gage } \\
\#\end{array}$ & \begin{tabular}{c} 
Loca- $_{\text {tion }^{1}}$ \\
\cline { 3 - 9 }
\end{tabular} & $\begin{array}{c}\text { Voltage } \\
\text { (volts) }\end{array}$ & $\begin{array}{c}\text { \% Strain } \\
\text { (in/in) }\end{array}$ & $\begin{array}{c}\text { Strain } \\
\text { Ratio to } \\
\text { Yield }\end{array}$ & $\begin{array}{c}\text { Voltage } \\
\text { (volts) }\end{array}$ & $\begin{array}{c}\text { \% Strain } \\
\text { (in/in) }\end{array}$ & $\begin{array}{c}\text { Strain } \\
\text { Ratio to } \\
\text { Yield }\end{array}$ \\
\hline \multirow{3}{*}{3} & 1 & $-135^{\circ}$ & 3.48 & 0.085 & 0.964 & 4.16 & 0.102 & 1.152 \\
\cline { 2 - 9 } & 2 & $-45^{\circ}$ & 2.805 & 0.069 & 0.777 & 3.33 & 0.081 & 0.922 \\
\cline { 2 - 9 } & 3 & $15^{\circ}$ & 4.77 & 0.117 & 1.321 & 4.07 & 0.100 & 1.127 \\
\cline { 2 - 9 } & 4 & $150^{\circ}$ & 2.724 & 0.067 & 0.754 & 3.47 & 0.085 & 0.961 \\
\hline \multirow{3}{*}{4} & 1 & $-135^{\circ}$ & 3.75 & 0.092 & 1.038 & 2.268 & 0.055 & 0.628 \\
\cline { 2 - 9 } & 2 & $-45^{\circ}$ & 3.97 & 0.097 & 1.099 & 3.109 & 0.076 & 0.861 \\
\cline { 2 - 9 } & 3 & $15^{\circ}$ & 4.91 & 0.120 & 1.360 & 4.53 & 0.111 & 1.254 \\
\cline { 2 - 9 } & 4 & $150^{\circ}$ & 2.249 & 0.055 & 0.623 & 2.214 & 0.054 & 0.613 \\
\hline \multirow{3}{*}{5} & 1 & $-135^{\circ}$ & 3.26 & 0.080 & 0.903 & 3.6 & 0.088 & 0.997 \\
\cline { 2 - 9 } & 2 & $-45^{\circ}$ & 2.911 & 0.071 & 0.806 & 2.48 & 0.061 & 0.687 \\
& 3 & $15^{\circ}$ & 4.59 & 0.112 & 1.271 & 4.25 & 0.104 & 1.177 \\
\hline
\end{tabular}

1 - Location measured in degrees circumferentially ( $C W$ from plan view), starting at closure bolt

2- Strain determined using 0.0002446 in/in per volt scale factor. Yield strain ratio based on nominal 25 Ksi yield. 
WSRC-MS-2002-00476

Table 2 Summary of Results for Drum \#4, Pre-Condition Drop

\begin{tabular}{|c|c|c|c|l|}
\hline Sensor & $\begin{array}{c}\text { Output } \\
\text { Signal }\end{array}$ & Scale Factor & $\begin{array}{c}\text { Physical } \\
\text { Value }\end{array}$ & Comments \\
\hline \hline Strain Gage \#1 & 0.661 volts & 0.0004892 strain $/$ volt & $\varepsilon=0.032 \%$ & $\begin{array}{l}\text { Pre-tension strain was } 0.055 \% \text {. Strain drop } \\
\text { to less than zero at drop for } 20 \mathrm{~ms} \text {, then } \\
\text { returned to } 0.032 \% .\end{array}$ \\
\hline Strain Gage \#2 & 1.230 volts & 0.0004892 strain $/$ volt & $\varepsilon=0.060 \%$ & $\begin{array}{l}\text { Pre-tension strain was } 0.076 \% \text {. Strain } \\
\text { oscillated between } 0.035 \% \text { and } 0.060 \% \text { for } \\
0.1 \text { sec }\end{array}$ \\
\hline Strain Gage \#3 & 1.571 volts & 0.0004892 strain $/$ volt & $\varepsilon=0.077 \%$ & $\begin{array}{l}\text { Pre-tension strain was } 0.111 \% \text { before drop. } \\
\text { Strain oscillated between } 0.111 \% \text { and } \\
0.075 \% \text { for } 0.1 \text { sec }\end{array}$ \\
\hline Strain Gage \#4 & Lost & 0.0004892 strain $/$ volt & no data & \\
\hline
\end{tabular}

Table 3 Summary of Results for Drum \#4, 30 Foot Drop

\begin{tabular}{|c|c|c|c|l|}
\hline Sensor & $\begin{array}{c}\text { Output } \\
\text { Signal }\end{array}$ & Scale Factor & $\begin{array}{c}\text { Physical } \\
\text { Value }\end{array}$ & Comments \\
\hline \hline Strain Gage \#1 & 0.245 volts & 0.0004892 strain/volt & $\varepsilon=0.012 \%$ & $\begin{array}{l}\text { Initial strain was 0.032\%. Signal showed } \\
\text { positive spike, then dropped to } \approx 0.35 \text { volts for } \\
0.6 \text { sec, then dropped to 0.245 volts. }\end{array}$ \\
\hline Strain Gage \#2 & -0.571 volts & 0.0004892 strain/volt & $\varepsilon=-0.028 \%$ & $\begin{array}{l}\text { Initial strain was 0.060\%. Drop induced an } \\
\text { abrupt, non-oscillating drop in gage voltage. }\end{array}$ \\
\hline Strain Gage \#3 & -12.95 volts & 0.0004892 strain/volt & $\varepsilon=-0.634 \%$ & $\begin{array}{l}\text { Negative magnitude exceeds machine limits. } \\
\text { Gage is assumed lost. }\end{array}$ \\
\hline Strain Gage \#4 & Lost & 0.0004892 strain/volt & no data & \\
\hline
\end{tabular}

Table 4 Summary of Results for Drum \#4, One Meter Pin Drop

\begin{tabular}{|c|c|c|c|c|}
\hline Sensor & $\begin{array}{c}\text { Output } \\
\text { Signal }\end{array}$ & Scale Factor & $\begin{array}{c}\text { Physical } \\
\text { Value } \\
\end{array}$ & Comments \\
\hline Strain Gage \#1 & 1.843 volts & 0.0004892 strain $/$ volt & $\Delta \varepsilon=-0.0077 \%$ & $\begin{array}{l}\text { Voltage was set to }+2 \text { volts before test, Impact } \\
\text { with pin increased the strain. Impact with } \\
\text { ground }(0.26 \text { seconds later) reduced the strain. } \\
\text { Strain after } 30 \text { ' drop was } 0.012 \% \text {, so positive } \\
\text { strain still indicated after three drops. }\end{array}$ \\
\hline Strain Gage \#2 & 1.478 volts & 0.0004892 strain $/$ volt & $\Delta \varepsilon=-0.0255 \%$ & $\begin{array}{l}\text { Voltage was set to }+2 \text { volts before test, Impact } \\
\text { caused reduction in indicated strain. Strain } \\
\text { after } 30^{\prime} \text { drop was negative, and was reduced } \\
\text { more after pin drop. }\end{array}$ \\
\hline Strain Gage \#3 & Lost & $0.0004892 \mathrm{strain} / \mathrm{volt}$ & no data & \\
\hline Strain Gage \#4 & Lost & 0.0004892 strain $/$ volt & no data & \\
\hline
\end{tabular}

Table 5 Summary of Results for Drum \#5, Pre-Condition Drop.

\begin{tabular}{|c|c|c|c|c|}
\hline Sensor & Output Signal & Scale Factor & $\begin{array}{c}\text { Physical } \\
\text { Value }\end{array}$ & Comments \\
\hline Strain Gage \#1 & 2.70 volts & 0.0002446 strain $/$ volt & $\varepsilon=0.065 \%$ & $\begin{array}{l}\text { Pre-tension strain was } 0.088 \% \text {. Strain } \\
\text { dropped to near zero at drop for } 20 \mathrm{~ms} \text {, then } \\
\text { returned to } 0.132 \% \text {. }\end{array}$ \\
\hline Strain Gage \#2 & 2.01 volts & 0.0002446 strain $/$ volt & $\varepsilon=0.049 \%$ & $\begin{array}{l}\text { Pre-tension strain was } 0.061 \% \text {. Output volts } \\
\text { oscillated between } 2.4 \text { and } 1.8 \text { volts for } 0.05 \\
\text { sec }\end{array}$ \\
\hline Strain Gage \#3 & 2.31 volts & 0.0002446 strain $/$ volt & $\varepsilon=0.057 \%$ & $\begin{array}{l}\text { Pre-tension strain was } 0.104 \% \text { before drop. } \\
\text { Strain oscillated for } 0.05 \mathrm{sec}\end{array}$ \\
\hline Strain Gage \#4 & 11 volts & 0.0002446 strain/volt & $0.27 \%$ & Gage is near impact point. \\
\hline
\end{tabular}


WSRC-MS-2002-00476

Table 6 Summary of Results for Drum \#5, 30 Foot Drop

\begin{tabular}{|c|c|c|c|l|}
\hline Sensor & Output Signal & Scale Factor & $\begin{array}{c}\text { Physical } \\
\text { Value }\end{array}$ & Comments \\
\hline \hline Strain Gage \#1 & 4.01 volts & 0.0002446 strain $/$ volt & $\varepsilon=0.098 \%$ & Gage output oscillates for 0.05 sec. \\
\hline Strain Gage \#2 & -2.25 volts & 0.0002446 strain $/$ volt & $\varepsilon=-0.055 \%$ & $\begin{array}{l}\text { Abrupt drop of voltage. Exceeded Dash 8 } \\
\text { recorder range. Voltage measured w/ Fluke }\end{array}$ \\
\hline Strain Gage \#3 & 13.60 volts & 0.0002446 strain $/$ volt & $\varepsilon=0.333 \%$ & $\begin{array}{l}\text { Abrupt increase of voltage. Exceeded Dash } 8 \\
\text { recorder range. Voltage measured w/ Fluke }\end{array}$ \\
\hline Strain Gage \#4 & -1.88 & 0.0002446 strain $/$ volt & $\varepsilon=-0.046 \%$ & $\begin{array}{l}\text { Abrupt drop of voltage. Exceeded Dash } 8 \\
\text { recorder range. Voltage measured w/ Fluke }\end{array}$ \\
\hline
\end{tabular}

Table 7 Summary of Results for Drum \#5, One Meter Pin Drop

\begin{tabular}{|c|c|c|c|c|}
\hline Sensor & $\begin{array}{l}\text { Output } \\
\text { Signal }\end{array}$ & Scale Factor & $\begin{array}{c}\text { Physical } \\
\text { Value }\end{array}$ & Comments \\
\hline Strain Gage \#1 & 1.599 volts & 0.0004892 strain $/$ volt & $\Delta \varepsilon=-0.020 \%$ & $\begin{array}{l}\text { Voltage was set to }+2 \text { volts before test, Impact } \\
\text { with pin decreased the strain. Impact with } \\
\text { ground }(0.6 \text { seconds later) reduced the strain. } \\
\text { Strain after } 30 \mathrm{ft} \text { drop was } 0.098 \% \text {, so positive } \\
\text { strain still indicated after three drops. }\end{array}$ \\
\hline Strain Gage \#2 & 2.560 volts & 0.0004892 strain $/$ volt & $\Delta \varepsilon=0.027 \%$ & $\begin{array}{l}\text { Voltage was set to }+2 \text { volts before test, Impact } \\
\text { caused spike to }>4 \text { volts, then returned to } 2 \\
\text { volts, then increased to } 2.56 \text { volts after } 0.6 \mathrm{sec} \text {. }\end{array}$ \\
\hline Strain Gage \#3 & Lost & 0.0004892 strain $/$ volt & no data & \\
\hline Strain Gage \#4 & lost & 0.0004892 strain $/$ volt & no data & $\begin{array}{l}+1 \text { volt spike at impact }(+0.05 \% \text { strain }), \\
\text { returned to pre-strike strain, followed by loss } \\
\text { of gage at ground contact. }\end{array}$ \\
\hline
\end{tabular}

\section{References}

1. "Safety Analysis Report - Packages, 9965, 9968, 9972-9975 Packages," Westinghouse Savannah River Co. Report WSRC-SA-7, Rev. $10,2000$.
2. "Drop Tests of the Closure Ring for the 9975 Package," Allen C. Smith, Westinghouse Savannah River Co. Report WSRC-TR-200000140, Rev. 0, 2000. 